Historic, Archive Document

Do not assume content reflects current scientific knowledge, policies, or practices. 



\section{THIRTY-FIRST SEASON Wholesale Price List}

1890 Thirty First Season 1921 Whole Sale Price List

Thirty years of success entitles me to feel justly proud of my nursery stock, and I compete with all the legitimate growers in the American market. As to high standard, and excellence of my product. Dansville has an exceptional climate for the production of fruit trees and to this is added my love for the work, long years of experience and observation, and the ability to grow stock of the highest possible standard.

My present aim is to keep right at it, with an expanding business each season, getting a firmer grip on the good will of my customers, making the results count to our mutual benefit. It is a well known fact that there is a serious fruit tree shortage in the nurseries of America. I propagate my trees from imported French grown seedlings. War conditions has made it impossible for any American nurseryman to get within 30 per cent of his normal supply.

As it takes three years to mature a tree from the planting of a seedling, hence there is every indication of trees being scarce for years to come. It is to your advantage to order as early as possible this year. Do not wait until some of my varieties are exhausted.

\section{JOHN W. FINN'S, Wholesale Nurseries DÄNSVILLE, NEW YORK}

Buy your Trees, Plants and Vines Direct from the Nursery that Grows Them. Save the cost of Agents' commissions and other charges that you have been paying for. Let me have your business, and prove to you that I can save you money.

\section{CERTIFICATE}

This is to certify that the stock in the nursery of JOHN W. FINN'S WHOLESALE NURSERIES of Dansville, County of Livingston, State of New York, was duly examined in compliance with the provisions of Section 305 of the Agricultural Law, and was found to be apparently free from any contagious or infectious disease or diseases, or the San Jose Scale or other dangerously injurious insect pest or pests. This certificate expires Sept. 1, 1921.

Dated, Albany, N. Y., Oct. 3, 1920.

GEORGE E. HOGUE; Com. of Agriculture.

Wholesale Price of all Varieties of Hardy Apple Trees

\begin{tabular}{lllllllrrrr} 
& & \multicolumn{1}{c}{ Height } & \multicolumn{2}{c}{ Caliper } & Each & Ten & Hundred \\
Largest & Size & 2 Year & 6 to 7 Feet & $3 / 4$ and up XXX & $\$ .85$ & $\$ 8.00$ & $\$ 67.50$ \\
Medium & Size & 2 Year & 5 to 6 Feet & $5 / 8$ & to & $3 / 4$ & $X X$ & .80 & 7.50 & 62.50 \\
Smaller Size & 2 Year & 4 to 5 Feet & $1 / 2$ & to & $5 / 8$ & $X$ & .75 & 7.00 & 57.50
\end{tabular}

\section{SUMMER VARIETIES}

Early Harvest-Medium to large; pale yellow; fine flavor. Middle to end of August.

Red Astrachan-Large, roundish, nearly covered with deep crimson. August.

Sweet Bough-Large, pale, greenish yellow; tender and sweet. August.

Yellow Transparent-A Russian variety. Tree an upright grower and a very early and abundant bearer.

\section{AUTUMN VARIETIES}

Alexander - Of Russian origin. Large, deep red or crimson. October.

Pound Sweet-(Pumpkin Sweet) A very large, round, yellow russett apple. October and November.

Wealthy-Medium size, round, smooth and deep red; juicy, sub-acid and of good quality.

\section{WINTER VARIETIES}

Baldwin-The old stand by-the kind your neighbor has. December to April.

Ben Davis-Large, striped red, December to April.

Delicious - A remarkable variety. A splendid keeper and shipper. For this variety add $3 \mathrm{c}$ per tree. 
Fameuse-(Snow) Medium size, roundish, deep crimson. November to Jauuary.

Golden Russett-Medium to large size, dull russett. November.

Grimes Golden-Large size; rich golden yellow, of highest quality. January to April.

Hubnonesuch - Large; striped yellow and red of the highest quality. November to January.

Jonathon-Medium size; deep red and yellow; flesh tender, juicy and rich. November to March.

King $\rightarrow$ The king of them all; the old reliable. Handsome striped red of the largest size. November to March.

McIntosh Red-Large; flesh white, tender and juicy; a very popular kind; subacid. November to February.

Northern Spy-Large, roundish, striped led. January to June.

N. W. Greening-This apple is one of the best keepers we have, keeping in good condition generally until May.

Autumn Strawberry-Medium, streaked, tender, juicy, fine vigorous and productive. September to October.

Duchess of Oldenburg-Of Russian origin, large size, roundish, streaked with red and yellow. Ripens in August and September.

Fall Pippin-Very large; yellow; tender, juicy and of rich flavor. October and November.

Gravenstein-Large to very large, striped red and yellow; tender, juicy and high fiavored. One of the best of all fall apples. September to October.

Prices of All Varieties of Hardy Height

$\begin{array}{llll}\text { Largest Size } & 2 \text { Year } & 6 \text { to } 7 \text { Feet } \\ \text { Medium Size } & 2 \text { Year } & 5 \text { to } 6 \text { Feet } \\ \text { Smaller Size } & 2 \text { Year } & 4 \text { to } 5 \text { Feet }\end{array}$

SUMMER VARIETIES

Bartlett-Large; color when fully ripe is waxen yellow with red blush, juicy, melting, high flavored.

Clapp's Favorite-A superb, large, long, yellow pear, richly flushed with russett red next the sun, juicy and delightful, ripens before Bartlett. August.

Koonce-A very popular early rariety, fruit medium to large, yellow, one-half nearly covered with red.

Wilder-One of the very earliest pears, attractively colored and of excellent quality. Eariy August.

\section{AUTUMN VARIETIES}

Beurre Clairgeau-Very large, pyriform; yellow and red. October and Novem. ber.
Maiden Blush-Large; pale yellow with red cheeks. September to October.

Roxbury Russett - Medium to large; greenish or yellow russett, crisp; good sub-acid flavor.

R. I. Greening-The best of the green winter sorts and very well known, good cooking kind and good keeper.

Seek No Further - Medium to large, slightly russetted, with dull red stripes, tender; rich, spicy and fine.

Spitzenberg-A very popular apple, covering a large area; fair size; deep red; good keeper. November to April.

Stark-One of the best of all purpose apples grown. Large; roundish golden green shaded with dark and light red. January to May.

Stayman's Winesap - The best of the Winesap family without any exception. December to April.

Talman Sweet-Medium size, pale yellow, slightly tinged with red. November to April.

Wagner-Medium to large; deep red in the sun. December to May.

Winter Banana-Fruit large size, perfect in form; golden yellow and beautifully shaded and marked with bright crim. son red. November to January.

Wolf River-Very large, greenish yellow, covered with crimson. January to March.

\section{CRAB APPLES}

General Grant-Large, round, yellow, covered with stripes of red. September.

Hyslop-Fruit large, deep crimson; produced in clusters, flesh yellowish. October.

Transcendent-This is probably one of the best Crab apples; it is popular over the entire country.

\section{Upland Grown Standard Pear Trees}

$\begin{array}{lrrrr}\text { Caliper } & & \text { Each } & \text { Ten } & \text { Hundred } \\ 3 / 4 \text { and up } & X \times X & \$ .95 & \$ 9.00 & \$ 85.00 \\ 5 / 8 \text { to } 3 / 4 & \times X & .90 & 8.50 & 80.00 \\ 1 / 2 \text { to } 5 / 8 & X & .85 & 8.00 & 75.00\end{array}$

Beurre D'Anjou-A very fine pear, buttery and melting, with sprightly vinous flavor. October to January.

Duchess D'Angouleme-Among the largest of all our really good pears; greenish.yellow. October to November.

Seckel-A beautiful and delicious little pear that is the standard of excellence in its class. One of the richest and highest flavored pears known. September to October.

Worden Seckel-A worthy seedling of the famous old Seckel, quite as sweet and luscious, with the same rare flavor and aroma.

Sheldon- $\bar{A}$ large, round, russett and red pear of the very first quality. October. 


\section{WINTER VARIETIES}

Kiefer-One of the best market varieties and excellent keeper.

Lawrence-About medium, yellow, thickly dotted, and possesses a very fine, rich flavor. December to January.
Lincoln Coreless-Keeps well until the middle of March. Very large and of good quality.

Winter Nellis-One of the best early winter pears.

\section{Peach Trees}

Wholesale Prices of All Varieties of Hardy Peach Trees

\begin{tabular}{llll} 
& & & \multicolumn{2}{c}{ Height } \\
Largest Size & 1 Year & 5 to 6 Feet \\
Medium Size & 1 Year & 4 to 5 Feet \\
Smaller Size & 1 Year & 3 to 4 Feet
\end{tabular}

Belle of Georgia-Very large skin, white with red cheeks.

Carman-Large, resembles Elberta in shape, color creamy white with pale yellow blush. August.

Champion-A large handsome early variety, creamy white with red cheek, sweet, rich and juicy. Hardy and productive. I August.

Crawford Early-A magnificent large yellow peach of good quality. Early in September.

Crawford Late-A superb, large yellow peach. One of the best. Late Septem. ber.

Elberta-The leader of all peaches and the greatest commercial variety on the market. Early September.

Engle's Mammoth-Large, yellow. September.

Fitzgerald-Fruit large, brilliant color, bright yellow; suffused with red; flesh deep yellow, best quality. September.

\section{Caliper \\ 9-16 and up $X X X$ \\ Each \\ $\$ .80$ \\ Ten Hundred \\ $5-16$ to $7-16 \quad X \quad 70 \quad 6.50 \quad 50.00$ \\ Greensboro - The largest and most beautifully colored of all the early varieties. July.}

Kalamazoo-A leading market sort. Large, yellow, fine quality. Early Septemiber.

Yellow St. John-Nearly as largie as Crawford, fully equal in color. August.

Rochester-Is in a class by itself because it is the only good sized yellow freestone Peach of fine quality ready for market in the middle of August in the northern sitates. The fruit is large, yellow with a most attractive red blush; juicy and delicious and keeps well; an excellent shipper. Its greater sweetness over other Peaches requires only half the usual quanitity of sugar in canning. The tree is a strong grower; early and regular bearer of big crops, and absolutely hardy; two weeks ahead of Early Crawford - marturing when highest market price prevails.

\section{Wholesale Prices of all Varieties Hardy Upland Grown Plum Trees}

$\begin{array}{lll}\text { Largest Size } & 2 \text { Year } & 6 \text { to } 7 \text { Feet } \\ \text { Medium Size } & 2 \text { Year } & 5 \text { to } 6 \text { Feet } \\ \text { Smaller Size } & 2 \text { Year } & 4 \text { to } 5 \text { Feet }\end{array}$

\section{JAPANESE PLUMS}

Abundance-Fruit large and beautiful, amber turning to bright cherry red. August.

Burbank-Very large, clear cherry red; flesh deep yellow, sweet. August.

Red June-Medium to large, deep vermillion red, very showy, flesh light lem. in yellow, firm, delightful. Last of July:

Satsuma-Large, r'eddish purple, quality fine, delicious for canning. September.

Wickson - Very large, deep red with white bloom, flesh firm, sugary, delicious. September.

$\begin{array}{llrrr}\text { Caliper } & \text { Each } & \text { Ten } & \text { Hundred } \\ 3 / 4 \text { and Up } X \times X & \$ .95 & \$ 9.00 & \$ 85.00 \\ 5 / 8 \text { to } 3 / 4 & X X & .90 & 8.50 & 8000 \\ 1 / 2 \text { to } 5 / 8 & X & .85 & 8.00 & 75.00\end{array}$

EUROPEAN PLUMS

Bradshaw-Large. dark red. August.

Imperial Gage-Large, pale green, juicy, sweet, rich and excellent. Middle of August.

Lombard-Medium vio'et red, juicy, good; hardy and productive. The leading market variety. August.

Moore's Arctic-Small; purplish black. September.

Monarch - Tree robust, dense foliage, and abundant bearer, fruit very large, roundish, oval, dark purplish blue. Last of September.

Reine Claude-Very large, greenish yellow, juicy, excellent and of fine quality. September. 
Shipper's Pride-Large, dark purple. September.

Shropshire Damson-Large, amber color. September.

Yellow Egg-Large and beautiful, productive, egg shaped, yellow. August.

York State Prune-Large, blue, rich, juicy, fine. Best prune for market or garden. This prune originated here at Dansville as a seedling from German Prume and has been sold to fruit buyers for that variety in large quantities at profitable prices. Tree a vigorous grower and good bearer.

German Prune-A large, long oval variety, much esteemed for drying, color dark purple, of very agreeable flavor. Septemiber.

\section{SOUR AND SWEET CHERRY TREES}

$\begin{array}{lll}\text { Largest Size } & 2 \text { Year } & 6 \text { to } 7 \text { Feet } \\ \text { Medium Size } & 2 \text { Year } & 5 \text { to } 6 \text { Feet } \\ \text { Smaller Size } & 2 \text { Year } & 4 \text { to } 5 \text { Feet }\end{array}$

Ea. Richmond - This is a hardy red Cherry, fruiting on young trees soon after planting. June.

Eng. Morello-Very dark red, acid, of good quality. July 4 th to 15 th.

Large Montmorency-The most popular of all hardy cherries for market.

May Duke-An excellent variety with large, dark red fruit.

Louis Phillipe-Large and beautiful fruit of blackish red; flesh itender; mildly acid; one of the best. Middle of July.

Wragg-Dark red, firm. Ripens in July.

Bing-One of the most delicious sweet black cherries grown.

\section{BEARING AGE TREES}

For quick returns; many of these trees bore fruit in the nursery last season. Apples, Pears, Plums, Sweet Cherries, 8 to $10 \mathrm{ft}, 1$ to $1 \frac{1 / 2}{2}$ Inch.

Quinces, Peach, Sour Cherry, 7 to $\delta$ ft. 1 inch.

Price of all Bearing Age trees $\$ 1.25$ each, 10 for $\$ 12.010$.

I prepay transportation charges on all cash orders of $\$ 7.50$ or more, New York, Massachusetts, Rhode Island, Connecticut, Maine New Hampshire, Vermont, New Jersey, Pennsylvania, Deleware, Maryland, Ohio, Indiana, Michigan, Illinois.

\section{Wholesale Prices of all Varieties of Hardy Quince Trees}

Largest Size

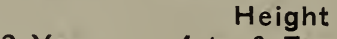

Medium Size

2 Year

4 to 6 Feet

2 Year

3 to 4 Feet

Champion-A prolific and constant bearer, ripens late.

Meech's-Fruit large, pear shaped, orange yellow, good quality.

Orange-Fruit large, bright yellow, of ex-
Caliper

$\begin{array}{ll}\text { and up } & \times X X \\ \text { to } 5 / 8 & X X\end{array}$
Each

$\$ .95$

.90
Black Tartarian-Very Large; bright

Gov. Wood-One of the best, clear light red, tender and delicious. Tree vigor-

Lambert-A valuable sweet cherry of the largest size, skin dark, purplish red.

apoleon-Fruit very large, orblong, pale

Schmidt's Big-Black, flesh dark, firm.

Windsor-Fruit large, liver colored, re-

Yellow Spanish-Large, pale yellow, with

cellent flavor. A vigorous grower and an immense producer.

Rea's Mammoth-A seedling of the Orainge, averaging much larger and of the same form and color.
Ten Hundred

$\$ 9.00 \quad \$ 85.00$

$8.50 \quad 80.00$

$8.00 \quad 75.00$

\section{Wholesale Price of Grapes, 2 Year, Vigorous Vines}

$50 \mathrm{c}$ each; 10 for $\$ 4.50 ; 100$ for $\$ 38.00$

Agawam-(Rogers No. 15) A dark red grape with fine flavor. Last of September.

Brighton-A large, delicious, sweet red grape. First of September.

Campbell's Early-Black, with purple bloom; bunch and berries large, juicy with rich sweet flavor.
Catawba-An old favorite red grape, Late September.

Concord-Decidedly the most popular grape in America.

Moore's Early-Bunch large, berry round, color black, with a heavy blue bloom.

Niagara-The vine is a strong grower and very hardy. 
Pocklington-Bunch large, berry is large, round, of a rich yellow color.
Worden--Said to be a seedling of the Con. cord; bunch large, compact, berries large.

\section{Gooseberries}

Wholesale Price 2 year bushes, 45 cents each, $\$ 4.00$ per $10, \$ 35.00$ per 100 .

PARCEL POST. Gooseberries can be sent by parcel post, postage prepaid, for 3 cents per bush extra.

Chautauqua-Very large, one of the best.

Downing-Whitish green, vigorous and prolific.

Houghton-A medium sized American variety, red, bears abundant.
Industry-An English variety, red.

Red Jacket-An American seedling of large size; smooth, prolific and hardy, of best quality. A wonderful cropper.

\section{CURRANTS}

\section{Wholesale Prices of all Varieties of Currant Bushes}

2. Year No. 1 Strong Vines

Red Cross--A strong growing variety, cluster long; berry medium to large, bright red.

White Grape--Very large; yellowish white.

\section{RED AND BLA CK RASPBERRIES}

Cumberland, Gregg, Kansas, Columbia Purple, Plum Farmer, Cuthbert, Marlboro, St. Regis. Price: 10 for 75 cents; 100 for $\$ 5.00 ; 1000$ for $\$ 35.00$

\section{BLACKBERRIES}

Eldorado, Snyder, Blowers, Kittatinny, Erie, Rathbun. Price, 10 for $\$ 1.00$; 100 for $\$ 6.00 ; 1000$ for $\$ 40.00$.

\section{STRAWBERRIES}

Glen Mary, Senator Dunlap, Candy, Haverland, Sample. Price: 100 for $\$ 1.25 ; 1000$ for $\$ 9.00$.

\section{RHUBARB OR PIE PLANT}

Linnaeus and Early Scarlet, strong 2 yr. Plants. Price, each 20c; 10 for $\$ 1.50 ; 100$ for $\$ 10.00$.

\section{ASPARAGUS}

Conover's Colossal, Palmetto and Columbian Mammoth White, Strong 2 year plants. Price, 10 for $50 \mathrm{c} ; 100$ for $\$ 2.00 ; 1000$ for $\$ 12.00$.

\section{ORNAMENTAL}

Cut Leaf Weeping Birch, 5 to 6 feet, each $\$ 1.50,10$ for $\$ 12.00$.

Tree Hydrangea, 3 to -4 feet, each $\$ 1.00,10$ for $\$ 8.00$.

Tea's Weeping Mulberry, 4 to 5 feet, each $\$ 2.00$.

Elm, the most admired of all American trees, 6 to 8 feet, each $75 \mathrm{c} ; 10$ for $\$ 6$.

Horse Chestnut (White Flowering), 4 to 5 feet, each $\$ 1.50 ; 10$ for $\$ 12$.

Silver-Leaved Maple, 6 to 8 feet, each $\$ 1.00 ; 10$ for $\$ 8$.

Norway Maple, 6 to 8 feet, each $\$ 1 ; 10$ for $\$ 8$.

Catalpa, Speciora, 5 to 7 feet, each $80 \mathrm{c} ; 10$ for $\$ 7$.

Russian Mulberry (bearing) 6 to 8 feet, each $\$ 1.50$; 10 for $\$ 12$.

Carolina Poplar, 8 to 10 feet; each $80 \mathrm{c} ; 10$ for $\$ 7$.

Thorn, Double Scarlet, 4 to 5 feet, each $\$ 1.25 ; 10$ for $\$ 11$.

Thorn, Double White, 4 to 5 feet, each $\$ 1.25$; 10 for $\$ 11$.

\section{CLIMBING VINES}

Ampelopsis, strong 2 year plants, each $50 c ; 10$ for $\$ 4.50$.

Wisteria, Climbing Purple, each $50 \mathrm{c}$; 10 for $\$ 4.50$.

Jackmanni, Clematis, 2 year plants, each $50 \mathrm{c} ; 10$ for $\$ 4.50$.

Paniculata, Clematis, 2 year plants, each 50 c; 10 for $\$ 4.50$. 


\section{Roses}

Wholesale Price of all Varieties of Rose Bushes

Strong Bushes 2 Year No. 1

Each

Ten extra.

PARCEL POST. Roses can be sent by parcel post, postage prepaid, for 3 cents per bush

Alfred Colomb-Brillianit carmine, crimson.

Augusta Mie-Delicate Pink.

Coquette des Alps-White, slightly shaded with carmine.

Gen. Jacqueminot-Brilliant crimson.

La France-Rich silvery rose color, the best of all.

Magna Charta-Pink and carmine.

Marshall P. Wilder-Bright cherry, Carmine.

Madame Plantier-Pure white.

Mrs. J. Laing-Delicate pinik color.

Margaret Dickson-White.

Paul Neyron-Deep rose color.

Prince Camilla de Rohan-Dark crimson.

HARDY CLIMBING ROSES

(Same price as bed roses)

Crimson Rambler-Of Oriental origin: best of all climbers, red.

Baltimore Belle-Pale, nearly white.

Baby Rambler-A dwarf, color red.

Dorothy Perkins-Beautiful pink, blooms all summer.

\section{HARDY FLOWERING SHRUBS}

Large Size, 2 years, each $50 \mathrm{c} ; 10$ for $\$ 4.50$.

Lilac, purple

Lilac, white

Calycanthus, sweet scenited

Spirea Van Houttei

Purple Fringe or Smoke Tree

Syringa or Mock Orange

Spiraea Billardi, blooms all summer
Bush Hydrangea, (Paniculata

(Grandiflora)

Althea, red purple and white

Snowball, Japanese

Snowiball, common

Quince, Japan Scarlet

Dbl. Flowering Althea (Rose of Sliaron)

Syringa, Golden

Weigela, Variegated-leaved

Deutzia, double flowering

\section{EVERGREENS}

Spruce, Norway, 2 to 3 feet, each $\$ 1 ; 10$ for $\$ 9 ; 100$ for $\$ 75$.

A lbor Vitae, American, 18 to 24 inches, each $\$ 1 ; 10$ for $\$ 9 ; 100$ for $\$ 75$.

\section{HEDGES}

California Privet, 2 year plants, 18 to 24 inches, each $20 \mathrm{c} ; 10$ for $\$ 1.50 ; 100$ for $\$ 15$.

Barberry Thunberg, 15 to 20 inches, $40 \mathrm{c}$ each; 10 for $\$ 3.50$; per $100 \$ 25.00$.

\section{SPECIAL NOTICE TO MY CUSTOMERS:}

DISCOUNT FOR CASH: I will allow a special discount of 5 per cent on cash orders of $\$ 5.00$ or over received before March 20 th, after that date 3 per cent on cash orders of $\$ 5.00$ or over.

TERMS: Cash with order, except with large orders, when satisfactory reference is giv. en, and then the order must be accompanied by one-fourth cash.

BOXING AND PACKING: We box and pack all orders without charge.

SPRING PACKING SEASON: The spring packing and shipping season usually begins here about April 1st and continues in to the month of May. The planting season is not regulated by any particular month or day, nor by the state of vegetation where planting is to be done, but by the condition of the trees to be planted. Hence, trees can be sent with safety from Dansville to localities several degrees sou'h even if they do not arrive until after the ordinary transplanting sason in that locality is past.

ORDERS SHOULD BE SENT IN as early as possible as I enter them for shipment in the order received. When sent early they are most sure of prompt attention and there is less danger of varieties being exhausted. ORDER NOW, do not wait until you are ready to plant. Your order will not be shipped until the proper time, or until you wish it. 
SHIPPING FACILITIES: My nurseries are located on the main lines of the $D$. L. \& $W$. and Erie Railroads. This gives the purchaser the benefit of inexpensive delivery.

REFERENCES: The Citizens' Bank, Dansville, N. Y., or any merchant in our city.

\section{Finn's Bargains in Special Collections No Discount on Collections}

Bearing Age Fruit Tree Collection, 5 trees, Value $\$ 6.25$ for $\$ 5.50$.

1 Baldwin Apple

1 Black Tartarian Sweet Cherry

1 Elberta Peach

1 Orange Quince

1 Bartlett Pear

1 Bart

Apple Tree Collection. All First Class. 10, 2 yr. 4 to 5 feet high, Value $\$ 7.00$ for $\$ 5.50$

2 Baldwin

2 Northern Spy

2 Mclinitosh Red
1 Delicious

1 Yellow Transparent.

1 Staymans Wine Sap

1 Winter Banana

Garden Collection of Fruit Trees. All First Class 2 Yr. old, 4 to 5 feet high

5 Trees, Value $\$ 4.25$ for $\$ 3.50$

1 Bartlett Pear.

1 Champion Quince
1 Ea. Richmond Sour Cherry

1 Elberta Peach

1 Delicious Apple

Mail Order Size Collection of Peach Trees, 2 to $2 \frac{1}{2}$ feet. Planters' Size 10 Trees, Value $\$ 6.50$ for $\$ 4.75$ Post Paid

3 Elberta

3 Rochester
2 Late Crawford

1 Champion

1 Yellow St. John

10 Strong 2 Year Grape Vines, Value $\$ 4.50$, for $\$ 4.25$ Post Paid
3 Concord
2 Brighton
1 Niagara
1 Moore's Early
1 Campbell's Early
1 Worden

10 Strong 2 Year Current Bushes, Value $\$ 3.25$ for $\$ 3.00$ Post Paid

3 Wilder

3 Red Cross
3 Cherry

1 Perfection
6 Cuthbert Red

6 Columbian Purple

25 Senator Dunlap Strawiberry
Berry Collection, 1 Year Strong Plants, $\$ 1.60$ Post Paid

6 Cumberland Black Raspberry

6 Blower Black

\section{Rose Bush Collection, 2 Year, Strong, Ever Blooming Bushes}

6 for $\$ 4.00$. Value $\$ 4.50$ Post Paid

1 Augusta Mie

1 La France

1 Marshal P. Wilder
1 Mrs. J. Lang

1 Paul Neyron

1 Coquette des Alps

Flowering Shrub Collection, $6,21 / 2$ to $3 \mathrm{ft}$. Shrubs, Value $\$ 3.00$ for $\$ 2.75$ Post Paid

1 Hydranga P. G.

1 Spirea Van Houttei

1 Japan Snow Ball
1 Purple Lilac

1 Syringa or Mock Orange

1 Deutzia Double Flowering 
John W. Finn, Esq.,

Dear Sir: Many thanks for prompt attention to my order of Fruit Trees. Bundle arrived in good shape yesterday.

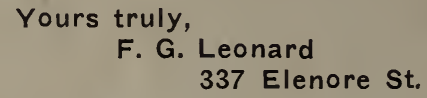

Mr. J. W. Finn,

3529 N. 16th St., Philadelphia, Pa., May 21, 1920

Dear Sir:-The trees I received from you were the finest I ever saw. They were in perfect condition, having been well packed. Will recommend your stock whenever I can.

$$
\text { Yours very truly, }
$$

\section{David G. Geikler}

Hillsdale, N. J., May 31, 1920

Mr. J. W. Finn,

Dear Sir:-Received the trees in good condition. They were fine. Will remember you for my future orders.

Yours truly,

Alfred Koestler

Mr. Finn,

South Westfield, N. J., June 1, 1920

Dear Sir:-Thanks for sending me such fine trees. Please send me price list of stock for I want more of them. Robert Graham.

Mr. J. W. Finn,

Eden, Texas, Apr. 20, 1920

Dansville, N. Y.

Dear Sir:-Received my fruit trees in fine condition. Am well pleased.

Very truly yours

Glynn Patten

Mr. John W. Finn,

Burlington, Me., Nov. 25, 1920

Dansville, N. Y. received.

Dear Sir:-Received the trees and bushes in excellent shape. The best I ever

Respectfully yours,

Mrs. Jos. Carey

Mr. John W. Finn,

Dansville, N. Y.

Dear Sir:-l received your trees for my last order. They were very nice. My neighbors want you to send them this order.

Yours very truly, Truman Davis

Mr. John W. Finn,

St. James, L. I., Apr. 28, 1920

Dansville, N. Y.,

Dear Sir:-The trees we ordered came in good condition, and two or three more than we sent for. Thanks for them. Enclosed find a money order for the second order. We certainly are pleased with your stock.

$$
\text { Very truly yours, }
$$

$$
\text { Silas E. Jay }
$$

Harpersville, N. Y., May 11, 1920

Mr. John W. Finn,

Dansville, N. Y.

Dear Sir:-l am very well pleased with my apple trees, and assure you when I get ready for more trees. You will surely get my order.

$$
\begin{aligned}
& \text { Yours very truly, } \\
& \text { John W. Finn }
\end{aligned}
$$

